\title{
PENERAPAN METODE ROLE PLAYING PADA MATA PELAJARAN PPKN DI SEKOLAH DASAR
}

\author{
A.Rahim $^{{ }^{1}}$, Risky Dwiprabowo ${ }^{2}$ \\ ${ }^{1,2}$ STKIP Kusuma Negara Jakarta \\ Jl Raya Bogor Km 24 Cijantung Jakarta Timur \\ *Corresponding Author: yonkkyl@stkipkusumanegara.ac.id

\begin{tabular}{l}
\hline Info Artikel \\
\hline Sejarah Artikel: \\
Diterima: $18 / 09 / 2020$ \\
Direvisi: $21 / 09 / 2020$ \\
Disetujui:30/09/2020 \\
\hline
\end{tabular} \\ Keywords: $\quad$ Role \\ Playing Method, \\ Election and Pilkada \\ Process, learning \\ outcomes.

\section{Abstract} \\ The background of this research is the fact of the low learning outcomes of PPKn among \\ SDN Jatimekar II Bekasi students, where most students have not reached the minimum \\ completeness standard (KKM). The purpose of this study was to improve student PPKn \\ learning outcomes in the Election and Pilkada Process material through the Role Playing \\ Method in grade VI students in the odd semester of the 2018/2019 academic year. This \\ research method is classroom action research (classroom action research). The model used \\ is the model used is the Kurt Lewin Model with 2 cycles, where in each cycle there are four \\ stages consisting of planning, acting, observing and reflecting. The research time was 4 \\ months, from August to November 2018 with 20 students as research subjects, while data \\ was collected through tests, interviews and observations. The results showed that there was a \\ significant increase in PPKn learning outcomes on the Election and Pilkada Process \\ material for grade VI students. This is evidenced by the results of the pre-cycle test 58.30 \\ increased to 71.08 in cycle I, and in cycle II increased with an average value of 87.50. The \\ results of this test are also supported by the results of interviews which show that PPKn \\ learning on the Election and Pilkada Process material through the Role Playing Method can \\ be fun, so that active learning is created.
}

\begin{abstract}
Abstrak
Latar belakang penelitian ini adalah adanya fakta rendahnya hasil belajar PPKn pada siswa SDN Jatimekar II Bekasi, di mana sebagian besar siswa belum mencapai standar ketuntasan minimal (KKM). Tujuan Penelitian ini adalah untuk meningkatkan hasil belajar PPKn) pada materi Proses Pemilu dan Pilkada melalui Metode Bermain Peran (Role Playing) pada siswa kelas VI semester ganjil tahun pelajaran 2018/2019. Metode penelitian ini adalah penelitian tindakan kelas (classroom action research). Model yang digunakan adalah Model yang digunakan adalah Model Kurt Lewin dengan 2 siklus, di mana dalam setiap siklus terdapat empat tahapan yang terdiri dari perencanaan (planning), pelaksanaan (acting), observasi (observing) dan Refleksi (reflecting). Waktu penelitian adalah 4 bulan yaitu dari bulan Agustus sampai bulan November 2018 dengan subjek penelitian sebanyak 20 siswa, sedangkan data dikumpulkan melalui test, wawancara dan observasi. Hasil penelitian menunjukkan bahwa terjadi peningkatan hasil belajar PPKn pada materi Proses Pemilu dan Pilkada yang signifikan pada siswa kelas VI. Hal ini dibuktikan dengan hasil tes pra siklus 58,30 meningkat menjadi 71,08 pada siklus I, dan pada siklus II meningkat dengan nilai ratarata 87,50. Hasil tes ini juga didukung dengan hasil wawancara yang menunjukkan bahwa pembelajaran PPKn materi Proses Pemilu dan Pilkada melalui Metode Bermain Peran (Role Playing) dapat menyenangkan, sehingga tercipta pembelajaran aktif.
\end{abstract}

\footnotetext{
"Alamat korespondensi:

STKIP Kusuma Negara Jakarta

J1 Raya Bogor Km 24 Cijantung Jakarta Timur

E-mail : yonkkyl@stkipkusumanegara.ac.id

(C) 2020 Program Studi PGSD Universitas Flores

Email: primagistrauniflor@ gmail.com
} 


\section{PENDAHULUAN}

Pembangunan nasional di bidang pendidikan adalah suatu upaya yang bertujuan mencerdaskan kehidupan bangsa dan meningkatkan kualitas manusia Indonesia dalam mewujudkan masyarakat adil, maju dan makmur berdasarkan Pancasila dan UndangUndang Dasar 1945 yang memungkinkan warganya mengembangkan diri sebagai manusia Indonesia seutuhnya. Untuk mewujudkan pembangunan nasional di bidang pendidikan diperlukan komitmen yang kuat dan konsisten serta peningkatan dan penyempurnaan penyelenggaraan pendidikan nasional yang disesuaikan dengan perkembangan ilmu pengetahuan dan teknologi, perkembangan masyarakat serta kebutuhan pembangunan.

Sistem pendidikan nasional yang menyeluruh dan terpadu dalam rangka pembangunan masyarakat Indonesia seutuhnya dan masyarakat Indonesia seluruhnya merupakan wahana kelangsungan hidup bangsa dan negara. Program pembangunan Indonesia juga menegaskan bahwa pendidikan yang diselenggarakan di lingkungan keluarga, sekolah (pemerintah) dan di masyarakat harus mampu meningkatkan kualitas manusia Indonesia dan menumbuhkan kesadaran serta sikap budaya bangsa untuk selalu berupaya menambah pengetahuan dan keterampilan serta mengamalkannya sehingga terwujud manusia dan masyarakat Indonesia yang beriman dan bertakwa kepada Tuhan Yang Maha Esa, lebih maju, mandiri dan berkualitas, menghargai setiap jenis pekerjaan yang memiliki harkat dan martabat sesuai dengan falsafah Pancasila.

Sekolah adalah suatu lembaga formal yang dikelola oleh pemerintah dan swasta dalam menyelenggarakan kegiatan pendidikan secara berencana, sengaja, terarah, sistematik oleh para pendidik profesional dengan program yang dituangkan ke dalam kurikulum untuk jangka waktu dan diikuti oleh siswa pada setiap jenjang pendidikan tertentu. Misalnya tingkat pendidikan dasar yang terdiri dari Sekolah Dasar (SD) yang lama pendidikannya 6 tahun, Sekolah Lanjutan Pertama (SLTP) yang lama pendidikannya 3 tahun dan Sekolah Lanjutan Atas (SLTA) yang lama pendidikannya 3 tahun.
Upaya untuk mencapai salah satu tujuan bernegara sebagaimana yang tercantum di dalam Pembukaan Undang-Undang Dasar 1945 alinea ke-4, yaitu meningkatkan kecerdasan kehidupan bangsa, maka pemerintah menetapkan Undang-Undang No. 20 Tahun 2004 tentang Sistem Pendidikan Nasional (Sisdiknas). Pendidikan Nasional bertujuan mencerdaskan kehidupan bangsa dan mengembangkan manusia seutuhnya, yaitu manusia yang beriman dan bertakwa kepada Tuhan Yang Maha Esa dan berbudi pekerti luhur, memiliki pengetahuan dan keterampilan, kesehatan rohani dan jasmani, kepribadian yang mantap dan mandiri serta bertanggung jawab kemasyarakatan dan kebangsaan.

Pernyataan di atas memperjelas pentingnya pendidikan dasar. Melalui program ini diharapkan sumber daya manusia Indonesia meningkat taraf pendidikannya. Dengan demikian diharapkan di masa yang akan datang lebih baik dalam pembentukan sikap, kecerdasan, keterampilan maupun kreativitasnya.

Program Wajib Belajar Pendidikan Dasar 12 Tahun perlu dipersiapkan sejak dini, yaitu kelas awal pendidikan dasar agar optimal dalam prestasi sehingga mampu menjawab tantangan zaman, berhasil guna dalam kehidupan sebagai wujud pendidikan berkelanjutan. Keberhasilan tersebut juga dapat dilakukan melalui pengembangan iklim belajar dan mengajar yang dapat memberikan dorongan untuk menumbuh kembangkan terciptanya individu kreatif dan penuh prakarsa yang bermoral dan berakhlak tinggi.

Berdasarkan hasil pengamatan dan pengalaman penulis selama ini, siswa kurang aktif dalam kegiatan belajar mengajar. Siswa cenderung tidak begitu tertarik dengan pelajaran Pendidikan Kewarganegaraan karena selama ini pelajaran Pendidikan Kewarganegaraan dianggap sebagai pelajaran yang hanya mementingkan hafalan semata, kurang menekankan aspek penalaran sehingga hasil belajar siswa pada mata pelajaran Pendidikan Kewarganegaraan di sekolah tidak maksimal.

Pada pengamatan awal di kelas 6 SDN Jatimekar II Bekasi dengan jumlah 20 siswa diperoleh nilai hasil belajar PPKn melalui tes tulis dengan rata - rata 56 pada pokok bahasan 
Proses Pemilu dan Pilkada. Nilai tersebut termasuk kategori rendah karena masih dibawah KKM yang telah ditentukan oleh SDN Jatimekar yaitu KKM 70. Bersamaan dengan itu dilakukan observasi/pengamatan dalam proses pembelajaran yang dilakukan guru ternyata kurang adanya penggunaan pendekatan, media dan metode yang tepat. Guru cenderung aktif dan siswa pasif. Selain itu dari wawancara dengan siswa juga didapat informasi bahwa siswa cenderung bosan dengan pembelajaran karena banyak yang harus dihafalkan.

Metode role playing merupakan suatu cara yang ditempuh dalam mempelajari PPKN dengan mengabstraksikan kenyataan yang ada dalam bentuk pemeranan. Menurut Greenblat (Suparno 2007) simulasi adalah model dinamika yang menggambarkan atau mengungkapkan system fisik (nonmanusia) atau social (manusia) yang diabstraksikan dari kenyataan dan disederhankan untuk proses belajar. .Metode simulasi atau role playing merupakan metode belajar yang menyenangkan. Menurut Uno (2008), Role playing atau bermain peran sebagai suatu model pembelajaran bertujuan untuk membantu siswa menemukan diri didunia social dan memecahkan dilemma dengan bantuan kelompok. Menurut Hamdani (2011) ,Role playing adalah suatu cara penguasaan bahan-bahab pelajaran melalui pengembangan imajinasi dan penghayatan siswa. Dari pengertian diatas dapat disimpulkan bahwa role playing atau bermain peran adalah suatu aktivitas pembelajaran sederhana yang terencana yang di rancang untuk mencapai tujuan-tujuan pembelajran.

Keberhasilan metode pembelajaran melalui bermain peran tergantung pada kualitas permainan peran yang diikuti dengan analis terhadapnya. Disamping itu, tergantung pada persepsi siswa tentang peran yang dimainkan terhadap situasi yang nyata (real life situation). Uno (2008) menyebutkan prosedur bermain peran terdiri atas Sembilan langkah, yaitu (1) pemanasan (warning up), (2) memilih partisipan, (3) menyiapkan pengamat (observer), (4)menata panggung, (5) memainkan peran (manggung), (6)diskusi dan evaluasi, (7) memainkan peran ulang (manggung ulang), (8) diskusi dan evaluasi kedua (9) berbagai pengalaman dan kesimpulan.

Menurut Miftahul Huda (2013), menjelaskan esensi role playing adalah keterlibatan partisipan dan peneliti dalam situasi permasalahan dan adanya keinginan untuk memunculkan resolusi damai serta memahami apa yang di hasilkan dari keterlibatan langsung ini.

Sedangkan menurut Kindsvatter, dkk (Suparno, 2007) ada beberapa langkah-langkah yang perlu diperhatikan dalam melaksanakan metode simulasi baik memerankan manusia maupun non manusia (1) orientasi, guru dan siswa mendiskusikan arti penting simulasi, menjelaskan tujuan yang ingin dicapai dari simulasi, dan persoalan yang ingin dipecahkan dalam simulasi, (2) persiapan peserta, guru dan siswa bersama-sama mempersiapkan scenario dan persoalan yang akan digunakan dalam simulasi, menentukan prosedur yang dilaksanakan siswa, memilih siswa yang akan memerankan, mengatur tata letak tempat, dan menentukan pengarah, (3) perjalanan simulasi, siswa diberikan kebebasan dalam melaksanakan simulasi dan guru berperan memfasilitasi agar simulasi berjalan lancer, (4) diskusi, pada akhir proses pembelajaran sebaiknya guru dan siswa bersama-sama mendiskusikan tentang simulasi yang telah dilaksanakan.

Berdasarkan penjelasan di atas langkah-langkah yang dapat di tempuh dalam penerapan metode role playing antara lain:

a) Pemilihan masalah oleh guru, yaitu mengemukakan masalah yang diangkat dari materi pokok bahasan agar mereka dapat merasakan masalah itu dan terdorong untuk mempelajarinya.

b) Pemilihan peran, yaitu memilih peran yang sesuai dengan permasalahan yang akan dibahas, mendeskripsikan karakter dan apa yang harus dikerjakan oleh para pemain.

c) Menyusun tahap-tahapbermain peran, dalalm hal ini guru telah membuat scenario atau dialog, namun siswa dapat menambahkan dialog sendiri yang sesuai dengan materi.

d) Menyiapkan pengamat, pengamat dari kegiatan ini adalah para siswa yang tidak 
sedang bermain dengan cara mengisi lembar aktifitas siswa.

e) Pemeranan/pelaksanaan, para siswa mulai beraksi sesuai dengan peran masing-masing yang terdapat pada scenario bermain peran.

f) Diskusi dan evaluasi, membeicarakan masalah dan pertanyaan-pertanyaan yang muncul dari siswa.

g) Pengambilan kesimpulan dari ppermainan atau bermain peran yang telah dilakukan.

Melalui metode role playing dapat melibatkan aspek-aspek kognitif, afektif, maupun psikomotorik. Dengan metode role playing, diharapkan siswa dapat menghayati dan berperan dalam berbagai figure khayalan atau figure sesungguhnya dalam berbagai situasi. Metode role playing yang direncanakan dengan baik dapat menanamkan kemampuan bertanggung jawab dalam bekerja sama dengan orang lain dan belajar mengambil keputusan dalam hubungan kerja kelompok.

Kelebihan metode role playing, Menurut mansyur dalam Ruminiati (2007) menerangkan bahwa metode role playing memiliki kelebihan seperti :

a) Melatih siswa untuk berkreatif dan berinisiatif.

b) Melatih siswa untuk memahami sesuatu dan mencoba melakukannya.

c) Memupuk siswa yang memiliki bakat seni dengan baik melalui bermain peran yang sering dilakukkannya denga metode ini.

d) Memupuk kerja sama antar teman dengan lebih baik pula

e) Membuat siswa merasa senang, karena dapat menghibur teman-temannya.

Pendapat lain Menurut Slameto (2003) menerangkan keunggulan role playing sebagai berikut:

a) Segera mendapat perhatian.

b) Dapat di pakai pada kelompok besar dan kecil.

c) Membantu anggota untuk menganalisa situasi.

d) Menambah rasa percaya diri pada peserta.

e) Membantu anggota dan siswa untuk menyelami masalah.

f) Membantu anggota mendapat pengalaman yang ada pada pikiran orang lain. g) Membangkitkan minat dan perhatian pada saat untuk memecahkan masalah

Kekurangan role playing menurut Mansyur (Ruminiati 2007 )antara lain adalah :

a) Pada umunya yang aktif hanya yang berperan saja.

b) Ini cenderung dominan unsure reaksinya dari pada kerjanya, karena berlatih role playing memerlukan banyak waktu dan tenaga.

c) Membutuhkan ruang yang cukup luas.

d) Sering mengganggu kelas di sebbelahnya. Menurut Abdul (2007) ,sebagai mana metode-metode mengajar lainya metode ini mengandung beberapa kelemahan diantaranya:

a) Jika siswa tidak disiapkan dengan baik ada kemungkinan tidak akan melakukan dengan sungguh-sungguh.

b) Role playing mungkin tidak akan berjalan dengan baik jika suasana kelas tidak mendukung.

c) Role playing tidak selamanya menuju arah yang diharapkan seseorang yang memainkanya. Bahkan juga mungkin akan berlawanan dengan apa yang diharapkannya.

d) Siswa sering mengalami kesulitan untuk memerankan paran secara baik khususnya jika siswa tidak diarahkan dengan baik. Siswa perlu mengenal dengan baik apa yang akan diperankanya.

e) Bermain memerlukan waktu yang banyak

f) Untuk dapat berjalan dengan baik, dalam role playing diperlukan kelompok yang sensitive, imajinatif, terbuka, saling mengenalsehingga dapat bekerja sama dengan baik

Pembelajaran seharusnya dikemas secara efektif dan menyenangkan. Sardiman A.M. (2011: 20) menjelaskan bahwa belajar merupakan perubahan tingkah laku atau penampilan, serta rangkaian kegiatan, misalnya dengan membaca, mengamati, mendengarkan, meniru dan lain sebagainya. Syaiful Bahri Djamarah (2002: 11) menyatakan bahwa belajar adalah suatu proses perubahan perilaku berkaitan pengalaman dan latihan. Artinya, tujuan pendidikan adalah perubahan tingkah laku, baik yang menyangkut pengetahuan, keterampilan maupun sikap, bahkan meliputi segenap aspek organisme atau pribadi. 
Depdiknas (2003: 3) dalam bukunya yang berjudul "Pedoman Pembelajaran Tuntas (Mastery Learning)" menjelaskan belajar pada hakikatnya adalah suatu aktivitas yang mengharapkan perubahan tingkah laku (behaviora change) pada individu yang belajar, perubahan tingkah laku tersebut terjadi karena usaha individu yang bersangkutan.

Lembaga pendidikan formal menggunakan suatu acuan penilaian tertentu untuk mengukur hasil belajar. Oemar Hamalik (2005: 25) menjelaskan hasil belajar adalah sesuatu yang diperoleh dari proses belajar. Hasil belajar tersebut diwujudkan dengan nilai atau angka tertentu yang mencerminkan suatu hasil, akibatnya adalah adanya perubahan kognitif, afektif, maupun psikomotorik. Nana Sudjana (2009: 22) menjelaskan hasil belajar adalah kemampuankemampuan yang dimiliki siswa setelah menerima pengalaman belajar. Hasil belajar merupakan perilaku berupa pengetahuan, keterampilan, sikap, informasi, strategi kognitif yang baru dan diperoleh siswa setelah berinteraksi dengan lingkungan dalam suatu suasana atau kondisi pembelajaran.

Berdasarkan pengertian di atas dapat disimpulkan bahwa hasil belajar adalah ukuran tingkat keberhasilan yang dapat dicapai oleh seorang siswa berdasar pengalaman yang diperoleh setelah dilakukan evaluasi berupa tes dan biasanya diwujudkan dengan nilai tertentu serta menyebabkan terjadinya perubahan kognitif, afektif, maupun psikomotorik.

Tujuan Penelitian ini adalah untuk meningkatkan hasil belajar PPKn siswa pada materi Proses Pemilu dan Pilkada melalui Metode Bermain Peran (Role Playing) pada siswa kelas VI semester ganjil tahun pelajaran 2018/2019.

\section{METODE PENELITIAN}

Metode penelitian yang digunakan dalam metode ini adalah metode kualitatif dengan pendekatan classroom action research, dimana peneliti ikut terjun langsung pada objek penelitian. Dengan demikian peneliti dapat melihat kesenjangan antara keadaan nyata dengan keadaan yang diharapkan, sehingga peneliti mengerti, memahami dan mengatasi masalah yang terjadi pada objek penelitian, sehingga peneliti dapat memecahkan permasalahan dan mengarahkan objek pada keadaan yang teratasi.

Intrumen yang digunakan dalam penelitian ini adalah instrument tes hasil belajar, wawancara, dan observasi. Subjek penelitian terdiri dari 20 siswa.

\section{HASIL DAN PEMBAHASAN}

\section{Hasil}

Metode pembelajaran Bermain Peran (Role playing) dan hasil observasi siswa yang diberikan dalam pembelajaran yang telah diberikan, memberikan hasil yang sangat memuaskan. Penulis menggunakan jawaban tersebut untuk mengetahui apakah pembelajaran PPKn dengan menggunakan metode pembelajaran Bermain Peran (Role Playing) tersebut dapat meningkatkan keaktifan hasil belajar siswa kelas IV SDN Jatimekar II Bekasi. Data berikut menunjukkan hasil belajar siswa dari pra siklus, siklus I dan siklus II.

Berdasarkan data dari hasil belajar siswa yang berjumlah 20 siswa hanya 7 siswa yang mampu mencapai KKM (Kriteria Ketuntasan Minimal), KKM pada pelajaran PPKn adalah 70. Dari data hasil belajar siswa pada pra siklus, dapat dilihat bahwa rata-rata yang diperoleh dari pelajaran pada pra siklus adalah 58.30. Dapat dilihat terdapat 7 siswa mencapai 35\% yang mencapai KKM 70, dan 13 siswa atau $65 \%$ masih dibawah KKM yang telah ditentukan.

Hasil tes pada siklus I dapat diketahui peningkatan hasil belajar siswa dengan nilai rata-rata 71,08. Nilai rata-rata tersebut menunjukkan peningkatan dibandingkan pada tahap pra siklus. Dari data hasil belajar siswa pada siklus I.dapat dilihat bahwa terdapat 13 siswa atau 65\% sudah mencapai KKM 70 dan 7 siswa atau $35 \%$ belum mencapai KKM 70.

Hasil tes pada siklus II dapat diketahui peningkatan hasil belajar siswa dengan nilai rata-rata 87,50. Nilai rata-rata tersebut menunjukkan peningkatan dibandingkan pada tahap siklus I. Baik rata-rata kelas dan jumlah siswa yang mencapai KKM telah mencapai hasil yang memuaskan yaitu dengan rata-rata hasil belajar kelas siswa adalah 87,50. Siswa yang tuntas mencapai 20 siswa atau $100 \%$ dari jumlah keseluruhan siswa

Hasil belajar siswa mengalami peningkatan. Hal ini jika dilihat dari pra siklus 
dan siklus I. Peningkatan tersebut juga telah memenuhi kriteria keberhasilan proses pada penelitian ini. Pada siklus II persentase siswa yang memenuhi KKM adalah sebesar 100\%. Hasil tersebut juga sudah memenuhi salah satu indikator keberhasilan. Maka dari itu, penelitian ini berhenti pada siklus II dan tidak dilanjutkan pada siklus berikutnya

Tabel 1.

Peningkatan Hasil Belajar Siswa

\begin{tabular}{|c|c|c|c|c|}
\hline \multirow[b]{2}{*}{ No } & \multirow[b]{2}{*}{ Kriteria } & \multicolumn{3}{|c|}{ Peningkatan } \\
\hline & & $\begin{array}{c}\text { Pra } \\
\text { Siklus }\end{array}$ & II & II \\
\hline 1. & Rata-rata & 58,30 & 71,08 & 87,50 \\
\hline 2. & $\begin{array}{c}\text { Ketuntasan } \\
\text { klasikal }\end{array}$ & $35 \%$ & $65 \%$ & $100 \%$ \\
\hline
\end{tabular}

Kesimpulan pada siklus II adalah kualitas proses pembelajaran mengalami peningkatan jika dibandingkan dengan kondisi pra siklus dan siklus I. Peningkatan tersebut juga telah memenuhi kriteria keberhasilan proses pada penelitian ini. Pada siklus II persentase siswa yang memenuhi kriteria ketuntasan menulis puisi adalah sebesar $100 \%$. Hasil tersebut juga sudah memenuhi salah satu indikator keberhasilan produk dalam penelitian ini yaitu jumlah siswa yang mencapai kriteria ketuntasan minimal sebesar 70. Maka dari itu, penelitian ini berhenti pada siklus II dan tidak dilanjutkan pada siklus berikutnya

Dari data aktifitas guru pada siklus I menunjukkan secara umum sudah baik, tetapi menurut penilaian observer masih ada kekurangan yaitu dalam hal pemberian tugas kurang jelas dan kurang mengaktifkan siswa. Kekurangan-kekurangan pada siklus I kemudian diperbaiki pada siklus II dan aktifitas guru pada siklus II secara umum sudah baik.

\section{Pembahasan}

Data peningkatan hasil belajar adalah data yang diperoleh dari hasil evaluasi dari setiap siklus. Dimana data tersebut diperoleh dengan cara memberikan serangkaian soal yang telah tersusun dari materi yang telah disampaikan kepada siswa. penyusunan soal dilakukan secara kolaboratif dengan melibatkan guru mata pelajaran yang mengampu. Soal yang telah dibuat kemudian diberikan kepada siswa untuk mengetahui kepemahaman siswa tentang materi yang disampaikan oleh pengajar. Pada penelitian ini dilakukan

Berdasarkan kondisi pada saat tersebut, peneliti berkolaborasi dengan guru untuk menerapkan metode pembelajaran role playing pada mata pelajaran PPKn. Pemilihan metode pembelajaran role playing disebabkan karena keunggulan yang dimilikinya. Metode pembelajaran role playing merupakan suatu cara penguasaan bahan-bahan pelajaran melalui pengembangan imajinasi dan penghayatan siswa (Hamdani, 2011: 87). Pada model ini, pengembangan imajinasi dan penghayatan dilakukan siswa dengan memerankannya dalam hal pemilu dan pemilukada. Pengembangan imajinasi dan penghayatan menjadikan siswa dapat lebih memahami materi atau konsep yang dipelajari.

Penggunaan metode pembelajaran role playing pada mata pelajaran PPKn tepat. Penggunaan metode role playing disebabkan karena keuntungan menggunakan metode itu sendiri, yaitu siswa lebih tertarik perhatianya pada pelajarannya; melalui bermain peran sendiri, mereka mudah memahami masalahmasalah sosial tersebut; melalui bermain peran sebagai orang lain, siswa dapat menempatkan diri seperti watak orang lain, dan siswa dapat merasakan perasaan orang lain sehingga menumbuhkan sikap saling perhatian

Peningkatan hasil belajar siswa terlihat dari hasil pra siklus, siklus I, dan siklus II. Adapun nilai rata-ratanya meningkat dari yang sebelumnya 58,30 pada pra siklus menjadi 71,08 pada siklus I, dan pada siklus II kembali naik dengan nilai rata-rata 87,50. Kemudian pada ketuntasan secara klasikal dapat dilihat bahwa terjadi peningkatan yaitu pada pra siklus $35 \%$ yang tuntas, pada siklus I meningkat menjadi $65 \%$ yang tuntas, dan pada siklus II terjadi peningkatan yang signifikan yaitu semua siswa atau $100 \%$ telah memenuhi kriteria keberhasilan penelitian.

Pelaksanaan pembelajaran melalui role playing secara umum berjalan dengan lancar, penerapan pembelajaran role playing membuat pembelajaran menjadi lebih bervariasi. Secara umum siswa lebih antusias pada pembelajaran, 
hal ini tebukti dengan kegaduhan suasana kelas dalam hal yang positif. Siswa menjadi lebih termotivasi dan aktif mendengarkan, hal ini sesuai dengan pendapat Chrisnaji (2018) bahwa motivasi merupakan pendorong dari diri seseorang untuk mencapai atau meraih tujuan yang diinginkan, selain itu para siswa mampu menyampaikan pendapat, dan melakukan penyanggahan pada kelompok yang menyajikan materi. Data peningkatan keaktifan belajar siswa diperoleh dari hasil pengamatan melalui lembar observasi yang dilakukan oleh guru pendamping. Pengamatan tersebut dilakukan selama pembelajaran berlangsung, observer mengamati kegiatan siswa selama pembelajaran dan merangkumnya dalam sebuah instrumen yang telah disediakan.

Aktivitas dan motivasi belajar siswa mengalami peningkatan karena siswa merasa tertarik menerapkan pembelajaran dengan metode role playing karena metode pembelajaran ini merupakan permainan yang menyenangkan bagi siswa. Hal ini sesuai dengan teori Hamdani (2011:87) yang menyatakan bahwa metode role playing merupakan metode yang diterapkan melalui permainan dan permainan merupakan pengalaman yang menyenangkan bagi siswa.

Nilai rata-rata siswa mengalami peningkatan karena metode role playing merupakan salah satu metode yang dapat meningkatkan pemahaman siswa terhadap materi pelajaran. Hal ini sesuai dengan teori yang dikemukakan oleh Uno Hamzah (2008:26), bahwa metode role playing dapat menjadi sarana bagi siswa untuk mendalami materi dalam mata pelajaran dengan berbagai cara.

Adanya peningkatan tersebut menunjukkan bahwa motivasi belajar siswa bertambah sehingga berdampak pada hasil belajar siswa yang mengalami peningkatan. Peningkatan tersebut sudah mencapai indikator keberhasilan yang ditentukan. Nilai siswa secara individu mengalami peningkatan yang cukup baik. Hal ini menjadikan nilai rata-rata kelas dan persentase ketuntasan secara klasikal juga meningkat. Dengan adanya peningkatan tersebut, maka terbukti bahwa penerapan metode pembelajaran role playing mampu meningkatkan hasil belajar siswa.
Hasil penelitian ini mendukung hasil penelitian yang dilakukan oleh Adelia Shinta Dewi (2010) yang menunjukkan bahwa penerapan model role playing telah berhasil meningkatkan hasil belajar siswa kelas IV SDN Purwodadi. Peningkatan hasil belajar tersebut dilihat dari adanya peningkatan nilai rata-rata 101 siswa dan peningkatan persentase jumlah siswa yang memperoleh nilai tuntas. Selain itu, hasil penelitian ini juga mendukung hasil penelitian yang dilakukan oleh Rulasmini Khotimah (2009) yang menunjukkan bahwa penerapan role playing dapat meningkatkan hasil belajar PKn siswa kelas II SDN Benerjowo. Adanya peningkatan nilai rata-rata dan jumlah siswa yang memperoleh nilai pada kategori tuntas membuktikan bahwa penerapan metode pembelajaran role playing dapat meningkatkan hasil belajar siswa kelas $\mathrm{V}$ pada mata pelajaran IPS di SD Negeri 2 Kecemen. Bagi siswa yang memperoleh nilai belum tuntas akan di berikan soal evaluasi sebagai perbaikan atau remidi

\section{SIMPULAN DAN SARAN}

Berdasarkan hasil penelitian dapat disimpulkan bahwa penerapan metode role playing dapat meningkatkan hasil belajar PPKn pada siswa SDN Jatimekar II Bekasi. Peningkatan hasil belajar siswa terlihat dari hasil tes pra siklus, siklus I, dan siklus II yang nilai rata-ratanya meningkat dari yang sebelumnya 58,30 pada pra siklus menjadi 71,08 pada siklus I, dan pada siklus II kembali naik dengan nilai ratarata 87,50. Kemudian pada ketuntasan secara klasikal dapat dilihat bahwa terjadi peningkatan yaitu pada pra siklus $35 \%$ yang tuntas, pada siklus I meningkat menjadi $65 \%$ yang tuntas, dan pada siklus II terjadi peningkatan yang signifikan yaitu semua siswa atau $100 \%$ memenuhi kriteria keberhasilan penelitian.

Adapun Saran pada penelitian ini (1) Bagi Siswa: disarankan agar hasil belajar yang baik yang telah diperoleh sebaiknya dipertahankan. (2) Bagi Guru: Guru harus membantu menciptakan suasana belajar yang menyenangkan, selain itu perlu disediakan alat peraga yang sesuai dengan materi yang diajarkan. Dalam pembelajaran yang menggunakan metode Role Playing, guru wajib memilih materi yang sesuai, karena 
tidak semua materi bisa di pelajari dengan menggunakan metode tersebut. (3) Bagi Sekolah Mengingat model pembelajaran dengan metode Role Playing dapat mendorong siswa lebih aktif dan dapat meningkatkan hasil belajar siswa, diharapkan setiap sekolah dapat menerapkan metode pembelajaran tersebut.

\section{DAFTAR PUSTAKA}

Abdul Aziz Wahab. (2007). Metode dan Model-Model Mengajar Ilmu Pengetahuan Sosial (IPS).Bandung; Alfabeta.

Chrisnaji Banindra Yudha (2018). Peningkatan motivasi belajar mahasiswa Pada mata Kuliah Konsep dasar matematika Melalui pendekatan Contextual Teaching and learning. Jurnal Pendidikan Dasar. Volume 9(1), $12-27$.

Depdiknas. (2003). Pedoman Pembelajaran Tuntas (Mastery Learning). Jakarta

Hamdani, (2011). Strategi Belajar Mengajar.Bandung: CV Pustaka Setia

Miftahul Huda.(2013). Model-Model Pengajaran dan Pembelajaran. Yogyakarta;Pustaka Pelajar.

Nana Sudjana. (2009). Penilaian Hasil Proses Belajar Mengajar. Bandung: Remaja Rosdakarya

Ruminiati. (2007). Pengembangan Pendidikan Kewarganegaraan SD. Dirjen Dikti Departemen Pendidikan Nasional.

Sardiman A.M. (2011). Interaksi \& Motivasi Belajar Mengajar. Jakarta: Raja Grafindo Persada

Slameto.(2003),Belajar dan Faktor-Faktor yang Mempengaruhinya. Jakarta;Rineka Cipta.

Suparno,Paul. (2007) .Metodologi pembelajaran fisika, Yogyakarta: Universitas Santa Darma.

Syaiful Bahri Djamarah. (2002). Strategi Belajar Mengajar. Jakarta: Rineka Cipta

Oemar Hamalik. (2008). Teknik Pengukuran dan Evaluasi Pendidikan. Bandung : Mandar Maju.
Uno Hamzah B.(2008). Model Pembelajaran. Jakarta; Bumi Aksara. 